\title{
A Case of Concurrent Molybdenosis, Secondary Copper, Cobalt and Selenium Deficiency in a Small Sheep Herd in Northern Germany
}

\author{
Carina Helmer ${ }^{1,+}{ }^{,}$Regina Hannemann ${ }^{1, \ddagger}$, Esther Humann-Ziehank ${ }^{1,}$, Sven Kleinschmidt ${ }^{2}{ }^{\oplus}$, Mareike Koelln ${ }^{3, \|}$, \\ Josef Kamphues ${ }^{3}$ and Martin Ganter ${ }^{1, *(D)}$
}

1 Clinic for Swine and Small Ruminants, University of Veterinary Medicine Hannover, Foundation, Bischofsholer Damm 15, 30173 Hannover, Germany; helmer@anicon.eu (C.H.); mail@tieraerztin-hannemann.de (R.H.); mail@labvetcon.de (E.H.-Z.)

2 Lower Saxony State Office for Consumer Protection and Food Safety, Food- and Veterinary Institute Braunschweig/Hannover, Eintrachtweg 17, 30173 Hannover, Germany; sven.kleinschmidt@laves.niedersachsen.de

3 Institute of Animal Nutrition, University of Veterinary Medicine Hannover, Foundation, Bischofsholer Damm 15, 30173 Hannover, Germany; dr.mareike.koelln@bosch-tiernahrung.de (M.K.); josef.kamhues@tiho-hannover.de (J.K.)

* Correspondence: martin.ganter@tiho-hannover.de

† Current Address: AniCon Labor GmbH, Muehlenstrasse 13, 49685 Hoeltinghausen, Germany; helmer@anicon.eu.

Citation: Helmer, C.; Hannemann,

R.; Humann-Ziehank, E.;

Kleinschmidt, S.; Koelln, M.;

Kamphues, J.; Ganter, M. A Case of

Concurrent Molybdenosis, Secondary

Copper, Cobalt and Selenium

Deficiency in a Small Sheep Herd in Northern Germany. Animals 2021, 11, 1864. https://doi.org/10.3390/ ani11071864

Academic Editors: Ilektra A. Fragkou and Tomás Landete-Castillejos

Received: 24 March 2021

Accepted: 18 June 2021

Published: 23 June 2021

Publisher's Note: MDPI stays neutral with regard to jurisdictional claims in published maps and institutional affiliations.

Copyright: (c) 2021 by the authors. Licensee MDPI, Basel, Switzerland. This article is an open access article distributed under the terms and conditions of the Creative Commons Attribution (CC BY) license (https:/ / creativecommons.org/licenses/by/ $4.0 /)$. $\ddagger$ Current Address: Veterinary Practice for Sheep, Goats, Llamas and Alpacas Dr. Hannemann, Domaene Ammerhof, 72070 Tuebingen, Germany; mail@tieraerztin-hannemann.de.

$\S$ Current Address: LABVETCON, Foehrenkamp 20, 31303 Burgdorf, Germany; mail@labvetcon.de.

|| Current Address: Bosch Tiernahrung GmbH \& Co. KG, Engelhardshauser Str. 55+57, 74572 Blaufelden-Wiesenbach, Germany; dr.mareike.koelln@bosch-tiernahrung.de.

Simple Summary: Mineral deficiencies are very widespread among small ruminant herds throughout the world and play a big role in small ruminant herd health management. This paper describes the occurrence of a primary molybdenosis causing secondary copper deficiency, combined with ovine white liver disease (cobalt deficiency) and white muscle disease (selenium deficiency) in a group of pastured ram lambs in Northern Germany. To the authors' knowledge, this is the first proven report of multiple trace element deficiencies in sheep in Germany for decades.

Abstract: To the author's knowledge this paper describes the first proven report of a combined primary molybdenosis, secondary copper $(\mathrm{Cu})$ deficiency, Ovine White Liver Disease-Cobalt (Co) deficiency, and selenium (Se) deficiency in a small pedigree herd of White Horned Heath sheep in Germany ( 8 ewes, 2 rams, 3 yearling ewes, 17 lambs) for decades. Clinical signs associated with these mineral deficiencies in a group of pastured ram lambs included emaciation, conjunctivitis, anaemia, growth retardation, discolouration of the wool and photodermatitis. Morbidities and mortalities arose in 4-6-month-old lambs despite intensive veterinary treatment in the summer of 2014 and 2015 ( $n=13,23 \%$ died). Se (3/5), Cu (4/7), and Co (3/3) deficiencies in combination with elevated values for Molybdenum (Mo, 2/2) were found. Hamburg is a large industrial city and an input of heavy metals from surrounding industries and coal-fired power stations in combination with a sandy, non-fertilised soil and monoculture grass species might offer a potential explanation for the severity of mineral deficiencies observed in this herd.

Keywords: cobalt; copper; selenium; deficiency; molybdenosis; sheep

\section{Introduction}

Molybdenum (Mo) is an essential trace element and part of the so-called molybdenum cofactor complex, which is required for three mammalian enzymes: xanthine oxidase, alde- 
hyde oxidase and sulphite oxidase [1]. Dietary Mo, iron (Fe) and Sulphur (S) concentrations are important factors influencing the absorption and availability of copper $(\mathrm{Cu})[2,3]$. Allen and Gawthrone [4] identified that increased Mo concentrations in forage led to interactions between molybdate and sulphide to form thiomolybdates in the rumen, which can bind $\mathrm{Cu}$ to form nutritionally unavailable complexes. Therefore, high levels of Mo have been associated with secondary $\mathrm{Cu}$ deficiency. Former mining areas are potential risk areas for the occurrence of high Mo concentrations in soil and grass [5]. Forage with moderate Mo concentrations of 5-10 mg/kg dry matter (DM) may affect bone development in young cattle (focal widenings of the growth plate, uncalcified cartilage), while concentrations greater than $10 \mathrm{mg} / \mathrm{kg}$ DM may result in diarrhoea, emaciation and achromotrichia (loss of hair pigment) [6]. However, the toxic level of Mo in forage consumed by ruminants is not well defined due to several factors. Laiblin and Stöber [7] suggest that molybdenosis might possibly occur at Mo concentrations of $1-10 \mathrm{mg} / \mathrm{kg}$ fresh matter in pasture grass if the $\mathrm{Cu}$ concentration is $<5 \mathrm{mg} / \mathrm{kg}$ fresh matter, whilst, $\mathrm{O}^{\prime}$ Connor et al. [8] suggested that plant Mo concentrations of $10 \mathrm{mg} / \mathrm{kg}$ DM may be a very conservative estimate for the threshold at which toxic effects may be observed. Miltimore and Mason [9] suggest that $\mathrm{Cu}$ :Mo ratios above 2 were suitable but lower ratios were associated with signs of $\mathrm{Cu}$ deficiency. The National Research Council [10] insists that $\mathrm{Cu}$ :Mo ratios of 10:1 are necessary for good ruminant health. Mills and Davis [11] revealed that severe diarrhoea might be a direct effect of Mo toxicity. However, most clinical effects of high Mo intake appear to be associated with the induced secondary $\mathrm{Cu}$ deficiency, called molybdenosis. This condition occurs under natural grazing conditions in many different parts of the world including Canada [1], the USA [12], the UK [13] and Sweden [14]. As indicated, thiomolybdates appear to induce $\mathrm{Cu}$ deficiency in several different ways [1]. Clinical manifestations of $\mathrm{Cu}$ deficiency include relatively unspecific signs such as ill thrift, emaciation and achromotrichia (cattle) or wool changes (sheep). Others include cardiovascular disorders (cattle), anaemia, growth retardation, infertility [15] and bone fragility [16]. A specific condition in sheep and goats related to $\mathrm{Cu}$ deficiency of pregnant ewes and young lambs results in enzootic ataxia of lambs. Most often ataxia is apparent immediately after birth, but it may also be delayed several weeks. Signs of ataxia include muscular incoordination, partial paralysis of the hindquarters, and degeneration of the myelin sheath of the nerve fibres. Lambs may be born weak or die due to the inability to suckle [15-17]. In addition to $\mathrm{Cu}$ deficiency, sheep are very susceptible to $\mathrm{Cu}$ toxicosis as well. $\mathrm{Cu}$ concentrations in pastures vary, however, most cases were caused by unintended exposure of sheep to $\mathrm{Cu}$ overload, induced by feeding concentrates or minerals produced for other farm animals than sheep, which provide higher $\mathrm{Cu}$ contents [18]. Unlike other species, sheep seem to have a limited capacity to accumulate large amounts of $\mathrm{Cu}$-metallothionein in the liver, and saturation occurs very quickly. The factors precipitating clinical chronic copper toxicity are unclear, but mostly include stress, acute infections and poor nutrition [19]. Noteworthy, the decrease of liver $\mathrm{Cu}$ concentration after exposure to $\mathrm{Cu}$ overload is very long with a half-life of liver $\mathrm{Cu}$ concentration $>2$ years as demonstrated in experimentally induced chronic $\mathrm{Cu}$ poisoning [20]. According to EU legislation (Annex/2010/349/EU), the maximum concentration of $\mathrm{Cu}$ in complete feedstuff with a moisture content of $12 \%$ is $15 \mathrm{mg} / \mathrm{kg}$ for ovines.

Ovine white liver disease (OWLD) is a disorder of the lipometabolism of sheep, usually growing lambs, and was first recorded in New Zealand in 1967 [21]. The trace element cobalt (Co) is an essential component for the synthesis of vitamin $\mathrm{B}_{12}$ (Cobalamin) by rumen microbes [22]. Thus, Co deficiency secondary results in a vitamin $B_{12}$ deficiency. Sheep appear to be susceptible to Co deficiency and develop normocytic and normochromic anaemia, anorexia, reduced weight gains and photosensitivity [23,24]. Moreover, lacrimation, scaly ears, discolouration of the wool, cardiovascular lesions and cerebrocortical necrosis [25-28] have been associated with low dietary levels of Co. For adult sheep grazing Co deficient pastures the amount of Co necessary to ensure optimal growth is $0.08 \mathrm{mg} / \mathrm{animal} / \mathrm{d}$. The requirement for young, rapidly growing lambs is greater during 
the first few months and should be at least $0.2 \mathrm{mg} /$ animal/day [29]. Clinicopathological abnormalities associated with Co deficiency are related to the inefficient metabolism of propionate [30]. Under normal conditions propionate is produced in the rumen, being metabolized to succinate via methylmalonate by the vitamin $B_{12}$-dependent enzyme methylmalonyl-CoA mutase. Succinate enters the citric acid circle to provide glucose as an energy source [31]. A lack of $C o$ and hence of vitamin $B_{12}$ leads to insufficient $\beta$-oxidation of fatty acids which accumulate in the hepatocytes and result in hepatic lipidosis. Gross pathological findings of OWLD include a remarkably pale, beige-coloured and friable liver. Liver histopathology reveals fatty degenerations of hepatocytes and accumulations of ceroid lipofuscin in Kupffer cells [32]. However, it must be admitted that even in cases of sufficient Co supplementation by the diet a ruminal function disorder might results in a vitamin $B_{12}$ deficiency due to the disfunction of the ruminal microbiota.

Deficiencies of vitamin E/Se are associated with nutritional myopathy with degenerative lesions of the skeletal muscles and heart muscle as well as hepatic necrosis, also known as white muscle disease [33]. Clinical manifestations associated with Vitamin E/Se deficiency in sheep include: ill-thrift in lambs, white muscle disease, lowered fertility and embryonic death, prematurity and perinatal death and abortions and immunosuppression [34,35].

This paper describes a combined occurrence of molybdenosis, secondary Cu deficiency, OWLD (Co deficiency) and selenium (Se) deficiency in a group of pastured ram lambs in Northern Germany. To the authors' knowledge, this is the first report of multiple trace element deficiencies in sheep in Germany for decades.

\section{Materials and Methods}

\subsection{Case Presentation}

This field investigation did not require official or institutional ethical approval because all samples were taken during routine diagnostic procedures to improve the herd health and were conducted in accordance with German animal welfare legislation and the EU Directive 2010/63/EU for animal experiments. All animals were handled according to high ethical standards and national legislation.

In October 2015 a German pedigree breeder with a small herd (8 ewes, 2 rams, 3 yearling ewes, and 17 lambs) of White Horned Heath sheep contacted the Clinic for Swine and Small Ruminants of the University of Veterinary Medicine Hannover, Foundation for a veterinary investigation into issues with lamb morbidity and mortalities. The farm is located in the North-Western part of Germany close to the Free City of Hamburg. The herd is managed outside at pasture year-round with access to an open stable at lambing time (March/April). Sheep are rotated regularly across two pastures during spring and summer. Pasture 1, based on sandy soil, is 2 hectares (ha) of a monoculture grass species (bluegrass, Poa pratensis) and sheep have been reared on this pasture for 3 years. Pasture 2 is a marshy soil type. It comprises 0.7 ha of diverse vegetation (pasture grass (Poa pratensis), timothy grass (Phleum pretense), meadow fescue (Festuca pratensis), velvet grass (Holcus lanatus), clover and legumes) and has been in use by sheep for 19 years. However, pasture grass dominates pasture 2 as well. Pasture 3 ( 0.5 ha) is used for lambing in March and April with the grazing of horses during the summer. No fertilizer is applied to pastures 1, 2 and 3. During the winter months (November until March) the herd is reared on temporary grassland which is fertilized (cattle manure and artificial fertilizer) and mowed regularly. Whilst sheep are at pasture, they are supplemented with a free-standing proprietary mineral block containing zinc $(6400 \mathrm{mg} / \mathrm{kg})$, manganese $(1300 \mathrm{mg} / \mathrm{kg})$, Co $(20 \mathrm{mg} / \mathrm{kg})$, iodine $(100 \mathrm{mg} / \mathrm{kg})$ and Se $(24 \mathrm{mg} / \mathrm{kg})$. The mineral block does not contain any $\mathrm{Cu}, \mathrm{Mo}$, S or Fe. Average intake, estimated by the owner based on block consumption, is approximately 2-4 g/animal/day, although significant intake deviations by some individuals, or in some periods cannot be ruled out. The recommendation for daily intake of the manufacturer is 20-30 g/animal/day. During the lambing period, the sheep are supplemented with ad libitum silage grass. The herd receives no concentrated feed and water access is freely 
available on all pastures (quality tested well water). Prior to these veterinary investigations, there was minimal veterinary practice contact. There was no history of preventative disease vaccination. The last deworming of the entire herd took place in spring 2015 with an oral moxidectin compound $\left(0.2 \mathrm{mg} / \mathrm{kg}\right.$ body weight, Cydectin ${ }^{\circledR} 0.1 \%$, Zoetis, Switzerland). No parasitological analysis or assessment of the FAMACHA@ score was performed before the anthelmintic treatment by the local veterinarian. The average number of raised lambs/ewe/year was 1.3-1.5. Abortions and premature births had not been observed during the previous lambing periods. The shepherd reported that the lambs, especially the ram lambs aged 4-6 months, had shown poor growth performance over the previous two years (13 lambs were affected, 3 died). In 2014, the shepherd reported signs of emaciation and shaggy, pale wool. Post mortem investigation of one of these animals revealed cachexia, and the liver was pale and of friable consistency. Hepatic lipidosis was confirmed by histopathology. Additionally, in 2015 the farmer reported that the lambs had shown signs of photodermatitis (crusty and ulcerated skin over the labia, nasal planum, ears and distal parts of the limbs) during the summer months. Three of the 13 (23\%) affected lambs in 2014 and 2015 died despite intensive treatment with oral moxidectin $(0.2 \mathrm{mg} / \mathrm{kg}$ body weight, Cyedctin ${ }^{\circledR} 0.1 \%$, Zoetis, Switzerland) and oral triclabendazole $(10 \mathrm{mg} / \mathrm{kg}$ body weight, Fasinex ${ }^{\circledR} 5 \%$, Novartis Tiergesundheit AG, Switzerland), supplementation of vitamin E/Se, and supplementation of B vitamins by the local veterinarian. Again no parasitological analysis or assessment of the FAMACHA® score or Se or Co status was performed by the local veterinarian prior to treatment. As the condition of the lambs did not improve despite the implemented treatment, the local veterinarian submitted one affected ram lamb to the clinic for further investigation on the 5th of October 2015. In autumn 2015, veterinary investigations performed by the Clinic of Swine and Small Ruminants included clinical examination of the entire herd ( 30 animals) was conducted.

\subsection{Clinical Examination}

An intensive clinical examination of a six-month-old entire ram lamb $(15.5 \mathrm{~kg})$ submitted to the clinic was performed on 5 October 2015.

\subsection{Farm Visit}

On the 29th of October 2015, a farm visit was made by an experienced sheep veterinarian $(\mathrm{CH})$. The animals were reared in four different groups on four different pastures: group 1: Eight ram lambs kept on pasture 3 until slaughter; group 2: Three yearling ewes and one ram kept on temporary pasture grass until lambing; group 3: Eight ewes and one ram kept on temporary pasture grass until lambing; group 4: Nine female lambs kept on temporary pasture grass until slaughter. The whole herd was clinically examined. Blood samples, faecal samples and liver samples were taken to the clinic for further analysis.

\subsection{Further Diagnostics}

An overview of samples gained for further diagnostics can be found in Table 1.

Table 1. Animals sampled for further investigations.

\begin{tabular}{|c|c|c|c|c|c|c|}
\hline Id & Sample Id & Age & Sex & Health Status & Tissue Examined & Date \\
\hline $\begin{array}{l}\text { lamb 1- } \\
\text { presented in the } \\
\text { clinic }\end{array}$ & 1 & 6 months & $\mathrm{m}$ & $\begin{array}{c}\text { emaciation, } \\
\text { photodermatitis, } \\
\text { conjunctivitis, apathy }\end{array}$ & $\begin{array}{c}\text { blood samples, faecal } \\
\text { sample, post mortem } \\
\text { investigation, liver } \\
\text { samples }\end{array}$ & $5 / 10 / 15$ \\
\hline $\begin{array}{l}\text { lamb 2- } \\
\text { farm visit }\end{array}$ & 2 & 6 months & $\mathrm{m}$ & unremarkable & $\begin{array}{c}\text { blood samples, } \\
\text { pooled faecal sample }\end{array}$ & $29 / 10 / 15$ \\
\hline $\begin{array}{l}\text { lamb 3- } \\
\text { farm visit }\end{array}$ & 3 & 6 months & $\mathrm{m}$ & $\begin{array}{c}\text { emaciation, } \\
\text { photodermatitis in } \\
\text { healing }\end{array}$ & $\begin{array}{c}\text { blood samples, } \\
\text { pooled faecal sample }\end{array}$ & $29 / 10 / 15$ \\
\hline
\end{tabular}


Table 1. Cont.

\begin{tabular}{|c|c|c|c|c|c|c|}
\hline Id & Sample Id & Age & Sex & Health Status & Tissue Examined & Date \\
\hline $\begin{array}{l}\text { ewe 1- } \\
\text { farm visit }\end{array}$ & 4 & 7 years & $\mathrm{f}$ & $\begin{array}{c}\text { emaciation, shaggy, } \\
\text { pale wool }\end{array}$ & $\begin{array}{c}\text { blood samples, } \\
\text { pooled faecal sample }\end{array}$ & $29 / 10 / 15$ \\
\hline $\begin{array}{l}\text { ewe 2- } \\
\text { farm visit }\end{array}$ & 5 & 3 years & $\mathrm{f}$ & unremarkable & $\begin{array}{c}\text { blood samples, } \\
\text { pooled faecal sample }\end{array}$ & $29 / 10 / 15$ \\
\hline $\begin{array}{c}\text { liver } 1- \\
\text { farm visit, frozen }\end{array}$ & 6 & $\begin{array}{c}\text { adult, } \\
\text { concrete age } u\end{array}$ & $\mathrm{f}$ & $\mathrm{u}$ & liver samples & $\begin{array}{l}\text { slaughtered in } \\
\text { autumn } 2014\end{array}$ \\
\hline $\begin{array}{c}\text { liver } 2- \\
\text { farm visit, frozen }\end{array}$ & 7 & $\begin{array}{c}\text { adult, } \\
\text { concrete age } u\end{array}$ & $\mathrm{f}$ & $\mathrm{u}$ & liver samples & $\begin{array}{l}\text { slaughtered in } \\
\text { autumn } 2014\end{array}$ \\
\hline
\end{tabular}

$\mathrm{u}=$ unknown, $\mathrm{m}=$ male, $\mathrm{f}=$ female.

\subsubsection{Blood and Liver Samples}

Blood samples were taken for further diagnostics (EDTA blood for haematology, Lithium-Heparin-Plasma and serum for biochemistry, serum for serology, Lithium-HeparinPlasma and serum for investigation of mineral balance). In total 5 animals were sampled: 1. The ram lamb submitted to the clinic, 2. two 6-month-old entire ram lambs (one affected lamb showing clinical signs of emaciation and photodermatitis in healing and one lamb in apparently healthy condition), 3. two ewes (one emaciated seven-year-old ewe with shaggy wool and a three-year-old ewe in good condition). EDTA anticoagulated blood was used to analyse, haemoglobin concentration and white and red blood cell count (Haematology analyser, Celltag alpha, Nihon Kohden, Kleinmachnow, Germany). Packed cell volume was analysed by centrifugation. Erythrocyte indices (MCH, MCV, MCHC) were calculated. Heparin plasma was analysed for total protein, albumin, bilirubin, plasma enzyme activities of creatine kinase (CK), aspartate-amino-transferase (ASAT), glutamate dehydrogenase (GLDH), and gamma-glutamyl-transferase (GGT) were determined by routine laboratory biochemistry according to Bickhardt and König [36]. Serum samples were analysed for Selenium (Se), copper $(\mathrm{Cu})$, and cobalt $(\mathrm{Co})$ concentrations. The results of the liver fluke Elisa were evaluated according to the manufacturer's instructions (IDEXX Fasciolosis Verification Test, IDEXX Laboratories, Ludwigsburg, Germany). Investigations of $\mathrm{Se}, \mathrm{Cu}, \mathrm{Co}$ and Mo concentrations in liver samples gained from 2 ewes of unknown age and health status slaughtered in 2014 and the ram lamb submitted to the clinic and euthanised due to grounds of animal welfare as well as plasma samples were performed by GFAAS and flame AAS (SOLAAR M, Thermo FisherScientific, Karlsruhe, Germany), respectively. Liver samples were digested using $4 \mathrm{~mL} \mathrm{HNO}_{3}(65 \%)$ and $1 \mathrm{ml}_{2} \mathrm{O}_{2}(30 \%)$ in a microwave digestion unit (Start, MLS GmbH, Leutkirch, Germany) before analysis [37,38].

\subsubsection{Faecal Samples}

Pooled faecal samples were taken from each of the 4 different groups for endoparasitic investigation during the farm visit. Furthermore, a single faecal sample of the ram lamb submitted to the clinic was gained. For examining the faecal samples, a modified version of the combined sedimentation-flotation process according to Benedek [39] was used.

\subsubsection{Post Mortem Investigation}

After three days of hospitalization and repeated clinical examination, the animal submitted to the clinic remained inappetent and was euthanized on the grounds of animal welfare. Post mortem investigation was performed at the Lower Saxony State Office for Consumer Protection and Food Safety, Food- and Veterinary Institute Braunschweig/Hannover. Gross necropsy examination was performed and tissue samples were collected from the major parenchymatous organs (lungs, heart, brain, liver, spleen, and kidneys), musculature and joints. Samples were fixed in $4 \%$ neutral buffered formalin and embedded in paraffin wax. Tissue sections $(4 \mu \mathrm{m})$ were stained with haematoxylin and eosin (HE). 


\subsubsection{Nutritional Assessment}

Feed samples of the permanent pasture grass from pastures 1 and 2, the pastures on which the sheep were reared during the summer months in which the clinical signs were observed, were collected (one rubbish bag (capacity $60 \mathrm{~L}$ ) per pasture; samples were obtained from all 4 corners and in a meandering pattern from the rest of the pasture) and submitted for feed analysis to the Institute of Animal Nutrition, University of Veterinary Medicine Hannover, Foundation. Dry Matter, Calcium (Ca), Phosphorus (P) and S contents were analysed according to the VDLUFA (book of methods) [40]. The reference ranges are set according to Kamphues et al. [41]. Sulphur was detected by using the Vario Max CNS (Elementar ${ }^{\circledR}$ ). The ground samples were mixed with wolfram (VI) oxide, weighed in ceramic crucibles and incinerated in the Vario Max CNS by $1140{ }^{\circ} \mathrm{C}$. The calcium content and trace elements were determined by atomic absorption spectrometry, phosphorus colourimetrically [42-45]. Molybdenum analysis was performed according to DIN EN ISO 17294-2 (2005) in an external laboratory (Sys Analytics Germany GmbH, Weilheim, Germany). Cobalt analysis was performed as described by Lange et al. [46]. In addition, water samples from both wells of these pastures were collected $(2 \mathrm{~L} /$ well collected in clean plastic bottles) and also sent for analytical examination to the Institute of Animal Nutrition, University of Veterinary Medicine Hannover, Foundation.

\section{Results}

\subsection{Clinical Examination}

Clinical examination of a six-month-old entire ram lamb $(15.5 \mathrm{~kg})$ submitted to the clinic revealed poor body condition with a body condition score (BCS) of 1.0 out of 5 [47], and a shaggy, discoloured coat. A bilateral mucopurulent nasal and ocular discharge, as well as hyperaemia of the sub-conjunctival mucous membranes, was observed. Cardiopulmonary auscultation and palpation of superficial lymph nodes were unremarkable. Rectal body temperature was $38.0^{\circ} \mathrm{C}$ and the breech dirtiness (DAG score [48]) was 0 out of 5 . The FAMACHA@ score was 3-4 on a scale ranging from 1-5 (pale mucous membranes). One rumen contraction in two minutes was noticed. Assessment of the claws, joints and external reproductive organs was unremarkable. Severe multifocal pinhead-sized, encrusted, hyperaemic skin lesions were observed around the labia, the nose, the eyes and the ears. Externally, the nasal planum, periorbital skin and peri-auricular skin was bilaterally swollen, warm and appeared painful to palpation. Crusting of the skin could not be removed without loss of substance. Pruritus was not present. Based on clinical examination, the key clinical signs of note were emaciation, conjunctivitis and photodermatitis.

\subsection{Farm Visit}

Clinical examination of the entire herd during the farm visit which took place on the 29th of October 2015 revealed that ram lambs (group 1) were generally in poor body condition (average BCS was 1.5). Two ram lambs showed signs of conjunctivitis and photodermatitis in healing. The rest of the herd appeared to be clinically in good health except for one older ewe (7 years old), which was in a poor body condition (BCS 2) and also showed shaggy, pale wool with an open fleece.

\subsection{Further Diagnostics}

\subsubsection{Blood and Liver Samples}

The ram lamb admitted to the clinic (sample ID 1) showed a remarkable increase of liver enzyme activities (aspartate aminotransferase (ASAT), glutamate dehydrogenase (GLDH), gamma-glutamyltransferase (GGT)) as well as an increase of total bilirubin. Microcytic, hypochromic anaemia, slight hyperproteinaemia and hypoalbuminaemia were identified. Analysis of liver tissue revealed that lamb 1 showed a severe copper and cobalt deficiency. Se in serum was within the reference range. Two lambs were sampled during the farm visit (sample ID 2 and 3), both showed low copper concentrations in serum and slightly elevated GGT activity. Signs of anaemia were noted in the haematology profile of 
lamb 2 (sample ID 2). Serum samples from ewes 1 and 2 (sample IDs 4 and 5) were only investigated for Se and Cu. Ewe 1 showed a moderate Se deficiency. Analysis of livers from two slaughtered adult sheep (sample IDs 7 and 8) revealed both a Se and Co deficiency. A Cu deficiency was noted in sample ID 8 and high concentrations of Mo were found in both liver samples. A summary of all results gained from blood and liver samples can be found in Table 2.

Table 2. Blood and liver results of tested sheep.

\begin{tabular}{|c|c|c|c|c|c|c|c|}
\hline Sample ID & 1 & 2 & 3 & 4 & 5 & 6 & 7 \\
\hline $\begin{array}{c}\text { Selenium *** } \\
(\mathrm{s}: 80-500 \mu \mathrm{g} / \mathrm{L} \\
\mathrm{l}: 0.25-1.5 \mathrm{mg} / \mathrm{kg} \mathrm{FM})\end{array}$ & s: 83.5 & s: 125.2 & s: 112.3 & s: $60.9 \downarrow$ & s: 125.3 & 1: $0.109 \downarrow$ & 1: $0.099 \downarrow$ \\
\hline $\begin{array}{c}\text { Copper }{ }^{* * *} \text { (s: 7-24 } \\
\mu \mathrm{mol} / \mathrm{L} ; \\
\text { l: } 10-120 \mathrm{mg} / \mathrm{kg} \mathrm{FM})\end{array}$ & $\begin{array}{l}\text { s: } 10.9 \\
\text { 1: } \mathbf{1 . 4 5} \downarrow\end{array}$ & s: $5.8 \downarrow$ & s: $5.7 \downarrow$ & s: 13.7 & s: 12.3 & l: 24.2 & 1: $9.1 \downarrow$ \\
\hline $\begin{array}{c}\text { Cobalt }{ }^{* * *} \\
\text { (1: } 0.025-0.085 \mathrm{mg} / \mathrm{kg} \mathrm{FM})\end{array}$ & 1: $0.008 \downarrow$ & - & - & - & - & 1: $0.015 \downarrow$ & 1: $0.020 \downarrow$ \\
\hline $\begin{array}{c}\text { Molybdenum *** } \\
(1: 1.5-6 \mathrm{mg} / \mathrm{kg} \mathrm{DM})\end{array}$ & - & - & - & - & - & $1: 7 \uparrow$ & $1: 8.5 \uparrow$ \\
\hline $\begin{array}{l}\text { Haemoglobin * }(90-140 \\
\mathrm{g} / \mathrm{L})\end{array}$ & $84 \downarrow$ & 90 & 109 & - & - & - & - \\
\hline $\begin{array}{c}\text { Packed Cell volume * } \\
(0.27-0.41 \mathrm{~L} / \mathrm{L})\end{array}$ & $0.24 \downarrow$ & 0.3 & 0.36 & & & & \\
\hline $\begin{array}{c}\mathrm{MCH} * \\
(13-14 \mathrm{pg})\end{array}$ & $10.4 \downarrow$ & $10.5 \downarrow$ & $10.7 \downarrow$ & - & - & - & - \\
\hline $\begin{array}{c}\mathrm{MCV} * \\
(34-46 \mathrm{fL})\end{array}$ & $32 \downarrow$ & 35.1 & 35.3 & & & & \\
\hline $\begin{array}{c}\mathrm{MCHC}^{*} \\
(290-340 \mathrm{~g} / \mathrm{L})\end{array}$ & 323 & 300 & 303 & & & & \\
\hline $\begin{array}{c}\text { Bilirubin ** } \\
(0-10 \mu \mathrm{mol} / \mathrm{L})\end{array}$ & $13.13 \uparrow$ & - & - & - & - & - & - \\
\hline $\begin{array}{c}\text { Protein ** } \\
(52-70 \mathrm{~g} / \mathrm{L})\end{array}$ & $71.9 \uparrow$ & 62.5 & 66.2 & & & & \\
\hline $\begin{array}{l}\text { Albumin ** } \\
(27-39 \mathrm{~g} / \mathrm{L})\end{array}$ & $24.2 \downarrow$ & 36 & 31.8 & - & - & - & - \\
\hline $\begin{array}{c}\text { ASAT ** } \\
(30-80 \mathrm{U} / \mathrm{L})\end{array}$ & $589 \uparrow$ & 63 & 47 & - & - & - & - \\
\hline $\begin{array}{c}C K^{* *} \\
(10-230 \mathrm{U} / \mathrm{L})\end{array}$ & 87 & 78 & 100 & - & - & - & - \\
\hline $\begin{array}{l}\text { GLDH ** } \\
(2-12 \mathrm{U} / \mathrm{L})\end{array}$ & $525 \uparrow$ & 7 & 9 & - & - & - & - \\
\hline $\begin{array}{c}\text { GGT }^{* *} \\
(5-32 \mathrm{U} / \mathrm{L})\end{array}$ & $135 \uparrow$ & $34 \uparrow$ & $35 \uparrow$ & - & - & - & - \\
\hline
\end{tabular}

Sample ID according to Table 1; s: serum; l: liver, MCH: Mean Corpuscular Haemoglobin, MCV: Mean Corpuscular Volume, MCHC: Mean Corpuscular Haemoglobin Concentration. The number in brackets marks the reference range according to Weiss and Wardrop [49] *, Bickardt et al. [50] ${ }^{* *}$, and Puls (1995) [51] ***. Values, which are not reported (hyphen), were not tested. The deviating values are indicated in bold and marked with $\downarrow$ for values that are too low and $\uparrow$ for elevated values.

\subsubsection{Faecal Samples}

The single faecal sample of lamb 1, the pooled faecal sample of the group of ram lambs and the pooled faecal sample of the group of ewes and rams showed only low egg counts. The pooled faecal samples of the female lambs and yearling ewes revealed moderate egg counts for gastrointestinal nematodes (202 eggs/g faeces and 117 eggs/g faeces, 
respectively; Table 3). No gross signs of fasciolosis were evident following inspection of livers received from slaughtered lambs in the previous years. The liver fluke serology was performed on the serum sample of lamb 1 with a negative result. An overview of the results is displayed in Table 3.

Table 3. Results of faecal samples of the four different groups (pooled, farm visit) and lamb 1 (individual, clinic).

\begin{tabular}{|c|c|c|c|c|c|c|c|c|c|}
\hline $\begin{array}{c}\text { Faecal } \\
\text { Sample }\end{array}$ & $\begin{array}{l}\text { Coccidial } \\
\text { Oocysts/g } \\
\text { Faeces }\end{array}$ & $\begin{array}{c}\text { Gastrointestinal } \\
\text { Nematodes } \\
\text { Eggs/g Faeces }\end{array}$ & $\begin{array}{l}\text { Nematodirus } \\
\text { Eggs/g } \\
\text { Faeces }\end{array}$ & Trichuris & Capillaria & $\begin{array}{l}\text { Strongyloides } \\
\text { Eggs/g } \\
\text { Faeces }\end{array}$ & $\begin{array}{l}\text { Moniezia } \\
\text { spp. }\end{array}$ & $\begin{array}{l}\text { Dicrocoelium } \\
\text { dentriticum }\end{array}$ & $\begin{array}{l}\text { Fasciola } \\
\text { hepatica }\end{array}$ \\
\hline lamb 1 & 5 & 45 & 0 & - & - & 3 & - & - & - \\
\hline $\begin{array}{c}\text { ram } \\
\text { lambs }\end{array}$ & 17 & 7 & 33 & + & - & 10 & - & - & - \\
\hline $\begin{array}{l}\text { female } \\
\text { lambs }\end{array}$ & 12 & 202 & 0 & + & - & 17 & - & - & - \\
\hline $\begin{array}{c}\text { yearling } \\
\text { ewes } \\
\text { ewes }\end{array}$ & 5 & 117 & 2 & - & - & 4 & - & - & - \\
\hline $\begin{array}{l}\text { and } \\
\text { rams }\end{array}$ & 0 & 4 & 0 & - & - & 3 & - & - & - \\
\hline
\end{tabular}

$+=$ positive; $-=$ negative.

\subsubsection{Post Mortem Investigation}

Gross necropsy examination of lamb 1 (sample ID 1) revealed crusty and ulcerated skin over the nasal planum (region nasalis), ears and distal parts of the skin of all four limbs. The liver was friable with yellow discolouration. The remaining gross organ examination was unremarkable. Microscopical examination of the skin revealed a severe pustular to ulcerative dermatitis with orthokeratotic hyperkeratosis, multifocal epidermal hyperplasia and a mild multifocal histiocytic to suppurative infiltration. Hepatocytes showed severe accumulation of micro- and macrovesicular fat droplets with single-cell necrosis (fatty degeneration). Mild biliary hyperplasia with cholestasis and a mild periportal lymphocytic and histiocytic infiltration were also noted (Figure 1).

\subsubsection{Nutritional Assessment}

Results of the nutritional assessments are listed in Table 4. Samples of grass from pastures 1 and 2, identified elevated S, Fe and Mo, and low Se and Ca concentrations. The $\mathrm{Cu}$ : Mo-ratio was $<2: 1$ on both pastures. The analysis of the water samples was unremarkable (clear liquid, odourless, iron values $<0.066 \mathrm{mg} / \mathrm{L}$, the reference value [41]: $<3 \mathrm{mg} / \mathrm{L})$.

Table 4. Results of the feed analysis of pastures 1 and 2.

\begin{tabular}{cccc}
\hline & Reference Values & Pasture 1 & Pasture 2 \\
\hline $\begin{array}{c}\mathrm{DM}(\mathrm{g} / \mathrm{kg} \text { original } \\
\text { substance) }\end{array}$ & - & 205 & 214 \\
\hline $\mathrm{Ca}(\mathrm{g} / \mathrm{kg} \mathrm{DM})$ & $7.1^{*}$ & $4.66 \downarrow$ & $5.46 \downarrow$ \\
\hline $\mathrm{P}(\mathrm{g} / \mathrm{kg} \mathrm{DM})$ & $3.4^{*}$ & 4.02 & 3.55 \\
\hline $\mathrm{S}(\mathrm{g} / \mathrm{kg} \mathrm{DM})$ & $2.58^{* *}$ & $3.79 \uparrow$ & 2.60 \\
\hline $\mathrm{Fe}(\mathrm{mg} / \mathrm{kg} \mathrm{DM})$ & $50-280^{* * *}$ & $404 \uparrow$ & $531 \uparrow$ \\
\hline $\mathrm{Cu}(\mathrm{mg} / \mathrm{kg} \mathrm{DM})$ & $5-10^{* * *}$ & 9.26 & 8.61 \\
\hline $\mathrm{Co}(\mathrm{mg} / \mathrm{kg} \mathrm{DM})$ & $0.1-0.2^{*}$ & 0.124 & 0.16 \\
\hline
\end{tabular}


Table 4. Cont.

\begin{tabular}{cccc}
\hline & Reference Values & Pasture 1 & Pasture 2 \\
\hline Se $(\mathrm{mg} / \mathrm{kg} \mathrm{DM})$ & $0.4^{* * *} 1^{* * *}$ & $\mathbf{0 . 1 1 2} \downarrow$ & $\mathbf{0 . 0 1 8} \downarrow$ \\
\hline Mo $(\mathrm{mg} / \mathrm{kg} \mathrm{DM})$ & $0.5-3.5^{* * *}$ & $\mathbf{1 1 . 3} \uparrow$ & $\mathbf{6 . 3 4} \uparrow$ \\
\hline Cu: Mo-ratio & $\begin{array}{c}\text { Set point value: 6:1, } \\
2-3: 1 \text { limits of acceptability, } \\
<2: 1 \text { toxic }\end{array}$ & $\mathbf{0 . 8 : 1} \downarrow$ & $\mathbf{1 . 4 : 1} \downarrow$ \\
\hline
\end{tabular}

DM: dry matter, Ca: Calcium, P: Phosphorus, S: Sulphur, Fe: Iron, Cu: Copper, Co: Cobalt, Se: Selenium, Mo: Molybdenum; The reference ranges are set according to Kamphues et al. [41] *, Dohm [52] **, Puls [51] ***, and Laiblin and Stöber [7] ${ }^{* * * *}$. The deviating values are indicated in bold and marked with $\downarrow$ for values that are too low and $\uparrow$ for elevated values.

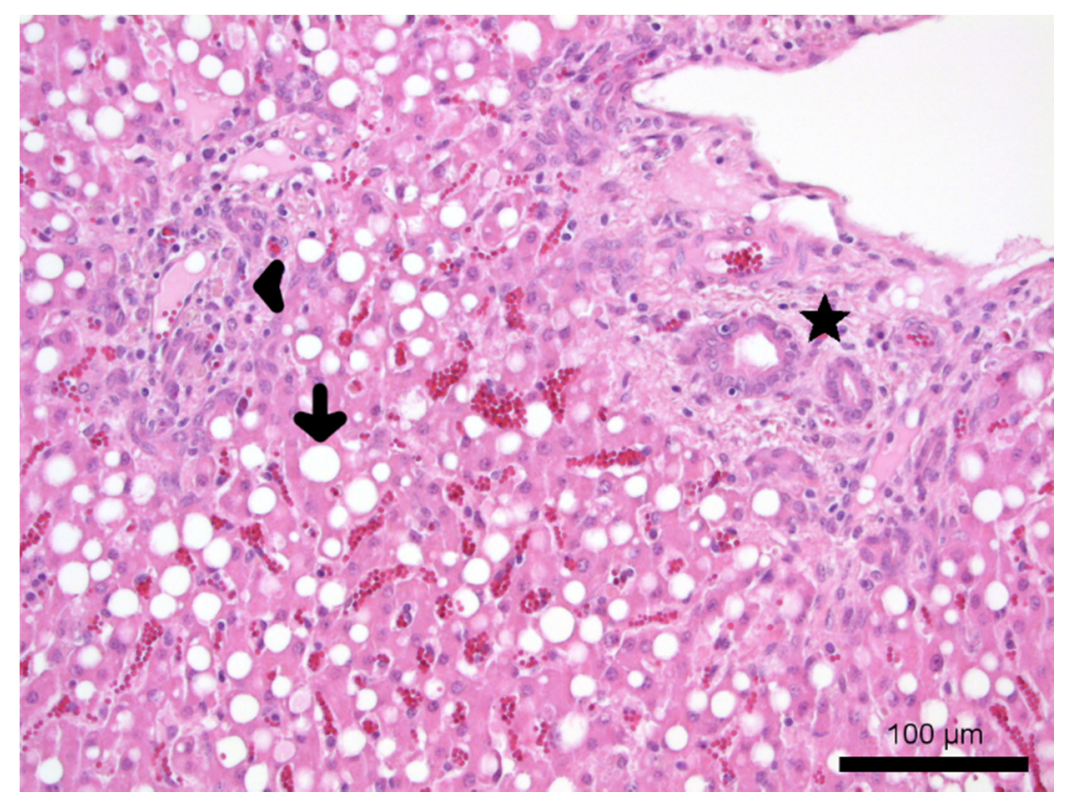

Figure 1. Histopathology of the liver: liver, HE, $20 \times$ magnification, hepatic lipidosis composed of fat droplets (arrow) within hepatocytes, a mild periportal lymphocytic and histiocytic infiltration (arrowhead) and mild biliary hyperplasia (asterisk). The sample was gained from the ram lamb submitted to the clinic for further investigations and euthanized on grounds of animal welfare.

\section{Discussion}

Veterinary diagnostic investigations indicate a concomitant molybdenosis, severe secondary $\mathrm{Cu}$ deficiency, OWLD (Co deficiency) and Se deficiency in this pedigree sheep herd. Small numbers of investigated animals and samples limit the scope of interferences between the different minerals in this case report so that the conclusions concerning their interference should be taken with some caution.

The ram lamb which was admitted to the clinic showed emaciation, ill-thrift, discolouration of the wool, anaemia, lacrimation, conjunctivitis and photodermatitis. Liver enzyme activities (ASAT, GLDH, GGT) were distinctly elevated due to serious liver damage. Furthermore, total bilirubin was increased. Examination of liver samples revealed a severe $\mathrm{Cu}$ and $\mathrm{Co}$ deficiency. Se measured in a serum sample was just within the reference range, which might be explained by the fact that the group of ram lambs was treated with a vitamin E/Se compound subcutaneously one week prior to admission to the clinic, and 3 out of 5 animals tested for Se showed a Se deficiency. Hence, a Se deficiency before treatment might be assumed, In addition, this group of lambs was treated with $\mathrm{B}$ vitamins, oral moxidectin $\left(0.2 \mathrm{mg} / \mathrm{kg}\right.$ body weight, Cydectin ${ }^{\circledR} 0.1 \%$, Zoetis, Switzerland) and oral triclabendazole $\left(10 \mathrm{mg} / \mathrm{kg}\right.$ body weight, Fasine ${ }^{\circledR} 5 \%$, Novartis Tiergesundheit AG, Switzerland) by the local veterinarian. Parasitological results of the faecal samples of this lambs were inconspicuous which is not surprising due to the performed deworming. 
A liver fluke serology was negative and post-mortem investigations showed no gross findings of fasciolosis. Cachexia, hepatic lipidosis and acute signs of photodermatitis in the area around the eyes, the ears and the nasal bridge were the main findings during necropsy.

As displayed in Table 2, 3 animals out of 5 showed Se deficiency and 1 animal was just within the reference range, 4 animals out of 7 showed $\mathrm{Cu}$ deficiency, 3 animals out of 3 showed Co deficiency and 2 animals out of 2 showed elevated Mo levels in a herd of 30 sheep. Due to the elevated Mo contents in two examined liver samples and the feed samples, a clinical picture of molybdenosis was assumed, and we conclude with caution that this led to secondary $\mathrm{Cu}$ deficiency. The farm is located $15 \mathrm{~km}$ away from a large Mo and Cadmium producing factory. Moreover, a coal fired power station is located nearby (distance: $30 \mathrm{~km}$ ). It can be assumed, but not proven, that an intake of heavy metals due to the surrounding industry is possible. Typical clinical signs of secondary $\mathrm{Cu}$ deficiency were observed in this sheep herd, especially in the growing ram lambs. This was supported by blood and liver results that found evidence of a mild to severe $\mathrm{Cu}$ deficiency. MacPherson et al. [53] stated that the relation between $\mathrm{Cu}$ in the liver and blood was poor. These findings were proven by West et al. [54] which suggested that measuring concentrations of $\mathrm{Cu}$ in serum or plasma are not appropriate indicators of marginal $\mathrm{Cu}$ status in sheep as the decrease in concentrations of $\mathrm{Cu}$ in the blood occur later in the development of $\mathrm{Cu}$ deficiency in sheep than in cattle, so that many sheep with depleted stores of $\mathrm{Cu}$ in the liver show adequate concentrations of $\mathrm{Cu}$ in the serum. Hence, $\mathrm{Cu}$ concentrations measured in serum samples of sheep are often not very reliable. However, if the $\mathrm{Cu}$ concentrations measured in serum samples are low, a severe copper deficiency and depleted stores of $\mathrm{Cu}$ in the liver can be assumed. Generally, it is more useful to investigate liver samples if disorders in the $\mathrm{Cu}$ balance should be addressed to be aware of potential disorders in $\mathrm{Cu}$ supplementation at an early convenience. Liver samples can be gained of slaughtered or dead animals as well as by liver biopsy [37]. Cu deficiency is aggravated by high dietary amounts of $\mathrm{S}$ and $\mathrm{Fe}$, which were also found in the examined pasture grass samples. The pastures (pasture 1 and 2), on which the herd grazes in spring and summer are not fertilized at all. Lambs are reared on pasture 1 and 2 dominated by monoculture pasture grass most of the time from birth until slaughter. By contrast, adult ewes and replacement yearling ewes are reared on fertilized and mowed pastures during the winter months. As the winter pastures are regularly fertilized by artificial fertilizer and cattle manure, which among others contents high levels of $\mathrm{Cu}$ [55], it can be assumed that the $\mathrm{Cu}$ deficiency, which arises during the summer months on the non-fertilized pastures, can be compensated by the adult sheep during the winter months. This might explain why clinical signs of $\mathrm{Cu}$ deficiency only appear in lambs aged 4-6 months, which at least for $\mathrm{Cu}$, is unusual, as the pregnant ewes can fill up their mineral balance during pregnancy so that the intrauterine development of the lambs is not disturbed. First clinical signs only appear after weaning when the lambs are fed by non-fertilized forage of pasture 1 and 2 . Thus, the peak of clinical signs only becomes obvious in the 4-6 months aged lambs. Management differences according to production stage and age of animals on this herd, and the different mineral nutrient requirements of growing ruminant animals might explain the owner's reports of poor performance in growing lambs. In general, adult sheep did not show overt clinical signs of deficiency during the herd visit. Although, deficiencies were identified in samples collected from adult slaughtered sheep, to date no reports of newborn lambs with signs of $\mathrm{Cu}$ deficiency characterized by hindlimb ataxia (colloquially known as "swayback syndrome") [56] have been reported in this herd.

A severe Co deficiency was found in three animals. The lamb admitted to the clinic showed typical clinical signs of OWLD including anaemia, anorexia, reduced weight gain, photosensitivity, lacrimation, scaly ears and discolouration of the wool $[23,24]$. Liver histopathological examinations revealed hepatic lipidosis, which is also typical for OWLD [32] due to the disorder of lipometabolism caused by Co and secondary Vitamin $\mathrm{B}_{12}$ deficiency. Due to the severe liver damage associated with OWLD, it is not uncommon to identify elevated liver enzymes (GGT, GLDH, AST), signs of emaciation and hepatic 
photodermatitis in affected animals [57]. Ulvund [58] found that in Norway especially the coastal areas are affected by Co deficiency. These finding could be proven by Sivertsen and Plassen [59]. Hence, it might be assumed that light and sandy soils are predisposed to low Co amounts. The absorption of Co through the plants depends on the $\mathrm{pH}$ value of the soil, and this decreases with increasing $\mathrm{pH}$ values. Additionally, the Co amount of the plants depends on the plant species. Grasses show the lowest Co content, whereas legumes, clover and lucerne contain 3-5 times more Co compared to grasses [60]. Pastures 1 and 2 which are used for growing lambs during summer are dominated by grass as a monoculture. Low Co contents in these forages are therefore not surprising.

Se deficiency is widespread in German sheep herds. Humann-Ziehank et al. [38] found that more than one-third of the investigated herds showed Se deficiency. Hence, if no mineral feed is provided or the Se content of the mineral feed is low then there is a risk for Se deficiency in grazing sheep herds. In this herd, the farmer reported that the sheep take only approximately $2-4 \mathrm{~g}$ mineral feed per animal per day of the offered licking mineral block. To assume an adequate mineral supply, adult sheep of approximately $60 \mathrm{~kg}$ should be fed 20-30 g/animal/day according to the manufacturer's instructions. The licking block is presented in a $2 \mathrm{~kg}$ bucket with ad libitum access on the ground with no protection against bad weather conditions. Hence, much of the licking stone is washed out by rain. Moreover, contaminations due to urine, faeces and dirt might lead to diminished intake of mineral feed. In this herd, 3 tested animals showed a Se deficiency and one animal was just within the reference range. The group of ram lambs had been treated with a vitamin E/Se compound subcutaneously one week prior to admission of lamb 1 to the clinic. Therefore, given the long-term nature of Se, it is unknown but was assumed that Se deficiency arose pre-treatment. Se deficiency might lead to nutritional muscular dystrophy (white muscle disease) which might clinically result in ill thrift in lambs, which could be observed in the ram lambs of this herd.

As this herd is reared on pastures close to Hamburg, which is a large industrial city, an input of heavy metals from surrounding industries and coal-fired power stations in combination with a non-fertilized, mostly sandy soil and monoculture pasture grass might be a possible explanation for the disorders in the mineral balance of this herd. Hence, an input of heavy metals from surrounding industries and coal mining and a prior lack of veterinary input on the herd was considered to contribute to the severe and concomitant trace element deficiencies identified.

As a result of veterinary diagnostic investigations, injecting $3 \mathrm{~mL}$ vitamin $\mathrm{E} / \mathrm{Se}$ per animal [Vitamin E-Selen (100 mg/mL + $0.658 \mathrm{mg} / \mathrm{mL})$, CP-Pharma, Burgdorf, Germany] and vitamin B compounds ( $3 \mathrm{~mL} /$ animal, VITAMIN-B-KOMPLEX pro inj., Serumwerk Bernburg, Bernburg, Germany) subcutaneously and providing a mineral feed containing $\mathrm{Co}, \mathrm{Cu}$ and higher amounts of Se fed at a dose of at least 20-30 g/animal/day according to the manufacturer's instructions the ram lambs recovered quickly and achieved their slaughter weight ( $35 \mathrm{~kg}$ live weight on average), even though this was achieved 4-6 weeks later than expected. Raisbeck et al. [12] showed that moderate $\mathrm{Cu}$ supplementation permitted cows to graze on pastures heavily contaminated with Mo with no adverse effects on general health or reproduction. Hence, a mineral feed for sheep containing $\mathrm{Cu}$ should be provided from now on being freely accessible for all animals at any time. To ensure this, the farmer was advised to build roofed facilities at head value and feed $20-30 \mathrm{~g} / \mathrm{animal} /$ day of a commercial mineral feed in powdered or pelletized form. To monitor the $\mathrm{Cu}$ intake of the herd the farmer was advised to send in liver samples of slaughtered animals every 3-6 months so that the risk of an accidental $\mathrm{Cu}$ intoxication can be minimized. In addition, all newborn lambs will from now on be treated with vitamin E/Se and vitamin B compounds within the first days of life. Se and Co statuses will also be addressed from liver samples of slaughtered animals regularly to monitor the general mineral status of the herd. 


\section{Conclusions}

This case report shows that several mineral deficiencies might be present at the same time in a sheep herd and that even under field conditions a detailed investigation is possible. Cases of poor growth performance in lambs should be investigated taking several mineral deficiencies, particularly $\mathrm{Co}, \mathrm{Cu}$ and $\mathrm{Se}$, into account. Clinical examination can give often only suspected diagnoses. To access possible mineral deficiencies, a nutritional assessment should be performed. Sampling should not only include blood, but also liver samples (biopsies, slaughter samples, or post mortem samples).

Author Contributions: Conceptualization, C.H. and M.G.; methodology, M.G., S.K. and M.K.; validation, C.H., R.H. and E.H.-Z.; formal analysis, C.H.; investigation, C.H. and R.H.; resources, M.G., S.K., M.K. and J.K.; data curation, C.H.; writing-original draft preparation, C.H.; writingreview and editing, R.H., E.H.-Z., S.K., M.K., J.K. and M.G.; visualization, C.H.; supervision, M.G. and J.K.; project administration, C.H. All authors have read and agreed to the published version of the manuscript.

Funding: This research did not receive any specific grant from funding agencies in the public, commercial, or not-for-profit sectors. This publication was supported by Deutsche Forschungsgemeinschaft and University of Veterinary Medicine Hannover, Foundation within the funding program Open Access Publishing.

Institutional Review Board Statement: Ethical review and approval were waived for the study was performed to evaluate and solve a clinical problem, which had been occurred spontaneously.

Data Availability Statement: Data is contained within the article.

Acknowledgments: The authors wish to thank the technical personnel of the Clinic for Swine and Small Ruminants, the Institute for Animal Nutrition, University of Veterinary Medicine, Hannover as well as the Lower Saxony State Office for Consumer Protection and Food Safety, Food and Veterinary Institute Braunschweig/Hannover for their excellent technical support. In addition, the authors would like to thank Frances Sherwood-Brock and Clare Joan Phythian for proofreading the English manuscript as well as the shepherd of the herd for their active involvement in these investigations.

Conflicts of Interest: The authors declare no conflict of interest.

\section{References}

1. Sardesai, V.M. Molybdenum: An essential trace element. Nutr. Clin. Pract. 1993, 8, 277-281. [CrossRef]

2. Gooneratne, S.R.; Buckley, W.T.; Christensen, D.A. Review of Copper deficiency and metabolism in ruminants. Can. J. Anim. Sci. 1989, 69, 819-845. [CrossRef]

3. Majak, W.; Steinke, D.; Lysyk, T.; Ogilvie, K.; McGillivray, J. Efficacy of copper supplementation in the prevention of molybdenosis in cattle. Rangel. Ecol. Manag. 2006, 59, 285-292. [CrossRef]

4. Allen, J.D.; Gawthrone, J.M. Involvement of the solid phase rumen digesta in the interaction between copper, molybdenum and sulfur in sheep. Br. J. Nutr. 1987, 58, 265-276. [CrossRef] [PubMed]

5. Gardner, W.C.; Broersma, K.; Popp, J.D.; Mir, Z.; Mir, P.S.; Buckley, W.T. Copper and health status of grazing high-molybdenum forage from reclaimed mining tailing site. Can. J. Anim. Sci. 2003, 83, 479-485. [CrossRef]

6. National Research Council. Mineral Tolerance of Domestic Animals; National Academy Press: Washington, DC, USA, 1980.

7. Laiblin, C.; Stöber, M. Fütterungs-, stoffwechsel-, mangel- und vergiftungs-bedingte Krankheiten mit Beteiligung mehrerer Organsysteme. In Innere Medizin und Chirurgie des Rindes, 5th ed.; Dirksen, G., Gründer, H.D., Stöber, M., Eds.; Parey in MVS Medizinverlage: Stuttgart, Germany, 2006; pp. 1266-1272.

8. O'Connor, G.A.; Brobst, R.B.; Chaney, R.L.; Kincaid, R.L.; McDowell, L.R.; Pierzynski, G.M.; Rubin, A.; Van Riper, G.G. A modified risk assessment to establish molybdenum standards for land application of biosolids. J. Environ. Qual. 2001, 30, 1490-1507. [CrossRef] [PubMed]

9. Miltimore, J.E.; Mason, J.L. Copper to molybdenum ratio and molybdenum and copper concentrations in ruminant feeds. Can. J. Anim. Sci. 1971, 51, 193-200. [CrossRef]

10. National Research Council. Nutritient Requirements of Beef Cattle, 7th ed.; National Academy Press: Washington, DC, USA, 2000.

11. Mills, C.F.; Davis, G.K. Molybdenum. In Trace Elements in Human and Animal Nutrition; Academic Press Inc.: London, UK, 1987; Volume 1, pp. 429-463.

12. Raisbeck, M.F.; Siemion, R.S.; Smith, M.A. Modest copper supplementation blocks molybdenosis in cattle. J. Vet. Diagn. Invest. 2006, 18, 566-572. [CrossRef] [PubMed] 
13. Humphries, W.R. Control of hypocupremia in cattle by addition of copper to water supplies. Vet. Rec. 1980, 106, 359-362. [CrossRef]

14. Frank, A. 'Mysterious' moose disease in Sweden. Similarities to copper deficiency and/or molybdenosis in cattle and sheep. Biochemical background of clinical signs and organ lesions. Sci. Total Environ. 1998, 209, 17-26. [CrossRef]

15. Howell, J.M. Nutrition and the nervous system in farm animals. World Rev. Nutr. Diet. 1970, 12, 377-412. [PubMed]

16. Buck, B.C.; Ulrich, R.; Taube, V.; Jacobsen, B.; Ganter, M. Osteopenie in Folge eines Kupfermangels bei einer zwergwüchsigen Thüringerwald Ziege. Tierärztl Prax 2012, 40, 45-52.

17. Underwood, E.J. Mineral imbalances in farm animals and their study and diagnosis with isotopic tracers. Energy Rev. 1976, 14, 591-619.

18. Humann, E. Investigations of Pathogenesis and Diagnostic of Chronic Copper Poisoning in Sheep. Ph.D. Thesis, University of Vet Med Hannover, Hanover, Germany, 1997.

19. López-Alonso, M.; Miranda, M. Copper Supplementation, a Challenge in Cattle. Animals 2020, 10, 1890. [CrossRef] [PubMed]

20. Humann-Ziehank, E.; Coenen, M.; Ganter, M.; Bickhardt, K. Long-Term Observation of Subclinical Chronic Copper Poisoning in Two Sheep Breeds. J. Vet. Med. A 2001, 48, 429-439. [CrossRef]

21. Martinovich, D. Sheep diseases in Northland associated with suspected toxic forage. In Proceedings of the New Zealand Veterinary Association Sheep Society; Annual Seminar 1974, Volume, Jan 1974; The Society of Sheep and Beef Cattle Veterinarians of the New Zealand Veterinary Association: Wellington, New Zealand, 1974; p. 99.

22. Smith, R.A.; Marston, H.R. Production, absorption and excretion of vitamin B12 in sheep. Br. J. Nutr. 1970, 24, 857-877. [CrossRef]

23. Ulvund, M.J.; Pestalozzi, M. Ovine white-liver disease (OWLD) in Norway: Clinical symptoms and preventive measures. Acta Vet. Scan. 1990, 31, 53-62. [CrossRef]

24. Vellema, P.; Moll, L.; Barkema, H.W.; Schukken, Y.H. Effect of cobalt supplementation on serum vitamin $B_{12}$ levels, weight gain and survival rate in lambs grazing cobalt-deficient pastures. Vet. Quart. 1997, 19, 1-5. [CrossRef]

25. Sargison, N.D.; Scott, P.R.; Wilson, D.J.; Bell, G.J.C.; Mauchline, S.; Rhind, S.M. Hepatic encephalopathy associated with cobalt deficiency and white liver disease in lambs. Vet. Rec. 2001, 149, 770-772. [CrossRef]

26. Rice, D.A.; McLoughlin, M.; Blachflower, W.J.; McMurray, C.H.; Goodall, E.A. Sequential changes in plasma methylmalonic acid and vitamin B12 in sheep eating cobalt-deficient grass. Biol. Trace Elem. Res. 1989, 22, 153-164. [CrossRef]

27. Mohammed, R.; Lamand, M. Cardivascular lesions in cobalt-vitamin B12 deficient sheep. Ann. Vet. Res. 1986, 17, 447-450.

28. MacPherson, A.; Moon, F.E.; Voss, R.C. Biochemical aspects of cobalt deficiency in sheep with special reference to vitamin status and a possible involvement in the aetiology of cerebrocortical necrosis. Br. Vet. J. 1976, 132, 294-308. [CrossRef]

29. Lee, H.J.; Marston, H.R. Requirement for cobalt of sheep grazed on cobalt-deficient pastures. Aust. J. Agric. Res. 1969, 20, 905-918. [CrossRef]

30. Martson, H.R.; Allen, S.H.; Smith, R.H. Primary metablic defect supervening on vitamin B12 deficiency in sheep. Nature 1961, 190, 1085-1092.

31. Gawthrone, J.M. The excretion of methylmalonic and formiminoglutamic acids during the induction and remission of vitamin B12 deficiency in sheep. Aust. J. Biol. Sci. 1968, 21, 789-794. [CrossRef] [PubMed]

32. Ulvund, M.J. Ovine white-liver disease (OWLD). Pathology. Acta Vet. Scand. 1990, 31, 309-324. [CrossRef]

33. Muth, O.H.; Schubert, J.R.; Oldfield, J.E. White muscle disease (myopathy) in lambs and calves. VII. Etiology and prophylaxis. Am. J. Vet. Res. 1961, 22, 466-469.

34. Andrews, E.D.; Hartley, W.J.; Grant, A.B. Se-responsive diseases if animals in New Zealand. N. Z. Vet. J. 1968, 16, 3-17. [CrossRef]

35. Bostedt, H. Serumenzymatische Untersuchungen bei Lämmern im Alter von 10-30 Tagen; gleichzeitig ein Beitrag zur Prophylaxe der enzootischen Muskeldystrophie. Berl. Münch. Tierärztl. Wschr. 1976, 89, 169-174.

36. Bickardt, K.; König, G. Blutmesswerte von gesunden Mutterschafen der Merino- und Schwarzkopfrasse zur Zeit der Geburt (Referenzwerte). Dtsch Tierärztl. Wschr. 1999, 106, 445-451.

37. Humann, E.; Risse, R.; Bruegmann, M.; Henze, P.; Ganter, M. Liver biopsy in sheep: Experiences with two different techniques. Tierärztl. Umsch. 1999, 54, 151-157.

38. Humann-Ziehank, E.; Tegtmeyer, P.; Seelig, B.; Roehrig, P.; Ganter, M. Variation of serum selenium concentrations in German sheep flocks and implications for herd health management consultancy. Acta Vet. Scan. 2013, 55, 1-8. [CrossRef] [PubMed]

39. Benedek, L. Allatorv. Lapok 1943, 66, 139.

40. Naumann, C.; Bassler, R. Methoden der landwirtschaftlichen Forschungs- und Untersuchungsanstalt, Biochemische Untersuchung von Futtermitteln, Methodenbuch 3 (Einschließlich der Achten Ergänzungen); VDLUFA: Darmstadt, Germany, 2012.

41. Kamphues, J.; Coenen, M.; Wolf, P.; Liesegang, A.; Eder, K.; Männer, K.; Iben, C.; Zebeli, Q.; Kienzle, E.; Zentek, J. Supplemente zur Tierernährung für Studium und Praxis; M. \& H. Schaper GmbH: Hannover, Germany, 2014; pp. 232, $294-295$.

42. El-Wahab, A.A.; Visscher, C.; Teitge, F.; Steinhagen, D. Choice preference of diets with different protein levels depending on water temperature in Nile tilapia. J. World Aquacult. Soc. 2020, 51, 512-526. [CrossRef]

43. Lineva, A.; Kirchner, R.; Kienzle, E.; Kamphues, J.; Dobenecker, B. A pilot study on in vitro solubility of phosphorus from mineral sources, feed ingredients and compound feed for pigs, poultry, dogs and cats. J. Anim. Physiol. Anim. Nutr. 2019, 103, 317-323. [CrossRef]

44. Visscher, C.; Middendorf, L.; Günther, R.; Engels, A.; Leibfacher, C.; Möhle, H.; Düngelhoef, K.; Weier, S.; Haider, W.; Radko, D. Fat content, fatty acid pattern and iron content in livers of turkeys with hepatic lipidosis. Lipids Health Dis. 2017, 16, 98. [CrossRef] 
45. Neustädter, L.-T.; Kamphues, J.; Ratert, C. Influences of different dietary contents of macrominerals on the availability of trace elements in horse. J. Anim. Physiol. Anim. Nutr. 2018, 102, e633-e640. [CrossRef] [PubMed]

46. Lange, M.; Höltershinken, M.; Scholz, H.; Vogt, C. Critical evaluation of internal standards and measuring conditions for the simultaneous determination of iodine and cobalt in bovine serum and urine (WedPo57). In Proceedings of the European Winter Conference on Plasma Spectrochemistry, Taormina, Italy, 18-23 February 2007.

47. Russel, A. Body condition scoring of sheep. In Pract. 1984, 6, 91-93. [CrossRef] [PubMed]

48. Dag Scoring, LambPlus, Profit through Science. Available online: http://www.sheep.ie/services/lambplus/files/dag_scoring. pdf (accessed on 3 February 2016).

49. Weiss, D.J.; Wardrop, K.J. Schalm's Veterinary Hematology; Wiley-Blackwell: Ames, IA, USA, 2010.

50. Bickhardt, K.; Dudziak, D.; Ganter, M.; Henze, P. Untersuchungen zur Altersabhängigkeit hämatologischer und blutchemischer Meßgrößen bei gesunden Schaflämmern-Ein Beitrag zur Definition von Referenzwerten beim Schaf. Dtsch. Tierärztl. Wschr. 1999, 106, 445-451.

51. Puls, R. Mineral Levels in Animal Health, 2nd ed.; Sherpa International: Clearbrook, BC, Canada, 1994.

52. Dohm, A. Der Schwefel- und Sulfat-Gehalt in Grund- und Kraftfuttermitteln-Einflüsse und Mögliche Bedeutung (Sulfur and Sulfate Contents in Roughages and Concentrates-Influence Sand Possible Significance). Ph.D. Thesis, University of Veterinary Medicine Hannover, Hanover, Germany, 2015.

53. Mac Pherson, A.; Brown, N.A.; Hemingway, R.C. The relation between the concentration of copper in the blood and livers of sheep. Vet. Rec. 1964, 76, 643-645.

54. West, D.M.; Bruère, A.N.; Ridler, A.L. Clinical aspects of trace element requirements of grazing ruminants with particularly reference to sheep and cattle. In The Sheep: Health, Disease and Production, 3rd ed.; VetLearn®: Wellington, New Zealand, 2009; pp. 129-180.

55. Nookabkaew, S.; Rangkadilok, N.; Prachoom, N.; Satayavivad, J. Concentrations of Trace Elements in Organic Fertilizers and Animal Manures and Feeds and Cadmium Contamination in Herbal Tea (Gynostemma pentaphyllum Makino). J. Agric. Food Chem. 2016, 64, 3119-3126. [CrossRef] [PubMed]

56. Barlow, R.M. Recent Advances in Swayback. Proc. R. Soc. Med. 1958, 51, 748-752. [CrossRef] [PubMed]

57. Ulvund, M.J. Ovine white-liver disease (OWLD). Changes in blood chemistry. Acta Vet. Scand. 1990, 31, 277-286. [CrossRef]

58. Ulvund, M.J. Ovine White-Liver Disease (OWLD). Manifestation of Cobalt/Vitamin B12 Deficiency in Lambs. Ph.D. Thesis, Norwegian College of Veterinary Medicine, Oslo, Norway, 1990.

59. Sivertsen, T.; Plassen, C. Hepatic Cobalt and Copper Levels in Lambs in Norway. Acta Vet. Scand. 2004, 45, 69-77. [CrossRef] [PubMed]

60. Ulvund, M.J.; Pestalozzi, M. Ovine white-liver disease (OWLD). Botanical and chemical composition of pasture grass. Acta Vet. Scan. 1990, 31, 257-265. [CrossRef] 